\title{
Sonic Hedgehog and Bone Morphogenetic Protein Regulate Interneuron Development from Dorsal Telencephalic Progenitors In Vitro
}

\author{
Alexandra Gulacsi and Laura Lillien \\ Department of Neurobiology and Pittsburgh Cancer Institute, University of Pittsburgh School of Medicine, Pittsburgh, Pennsylvania 15261
}

\begin{abstract}
Cortical progenitors are competent to produce interneurons, but do not generate large numbers of interneurons in vivo under normal circumstances. This could reflect the absence of an inductive signal in the environment of the dorsal telencephalon and/or the presence of an inhibitory signal. To determine whether either or both mechanisms regulate interneuron generation, progenitors in dorsomedial and dorsolateral wall explants of mouse telencephalon were marked with a retrovirus and cultured under several conditions. When cultured separately, progenitors in dorsomedial wall explants produced fewer GABAergic interneurons than progenitors in dorsolateral wall explants. When cocultured with ventral telencephalic cells, however, dorsomedial wall progenitors produced more GABAergic interneurons than in dorsomedial wall explants alone. The inductive effect of ventral telencephalon depended on sonic hedgehog (Shh) and could be mimicked by exogenous Shh. In contrast, exogenous bone morphogenetic protein 4 (BMP4) reduced the production of interneurons in dorsolateral wall explants and inhibited the induction by exogenous Shh. Moreover, inhibiting BMP signaling in dorsomedial wall progenitors with a dominant-negative BMP receptor $\mathrm{Ib}$ (dnBMPIb) virus increased their production of interneurons, even if Shh was blocked. Shh and dnBMPRIb increased proliferation and the generation of interneurons, but FGF2 did not induce interneurons, although it increased proliferation. This suggests that proliferation per se does not control the production of interneurons. Our findings suggest that the generation of interneurons by dorsal telencephalic progenitors is normally limited by excess levels of BMPs. Shh may promote the generation of interneurons by antagonizing BMP, but may not be required directly for the generation of interneurons.
\end{abstract}

Key words: cortex; progenitor; FGF; glutamate; GABA; neuronal differentiation

\section{Introduction}

There are two major classes of neurons in the neocortex and hippocampus: glutamatergic excitatory projection neurons and GABAergic inhibitory interneurons. Retroviral lineage analysis and several transgenic models revealed that distinct progenitor cells give rise to cortical projection neurons and interneurons, and that there is a relationship between cell phenotype and migration pattern (Parnavelas et al., 1991; Luskin et al., 1993; Mione et al., 1994, 1997; Tan et al., 1998). Most cortical pyramidal cells arise from progenitors in the cortical ventricular zone (VZ) and migrate radially to form the cortical plate (Sidman and Rakic, 1973; Rakic, 1990; Tan et al., 1998). In contrast, the vast majority of telencephalic interneurons originate subcortically in the ganglionic eminences (GEs) (Anderson et al., 1997a; Tamamaki et al., 1997).

Although these studies demonstrated that the majority of cortical interneurons arise from the ventral telencephalon, they did not rule out the possibility that the cortex produces some inter-

\footnotetext{
Received July 9, 2003; revised Sept. 18, 2003; accepted Sept. 22, 2003.

This work was supported by National Institutes of Health Grant NS38306. We thank Jennifer Phillips and Kristi Weigle for technical assistance and Amy Sinor and Dr. Stewart Anderson for their comments on this manuscript.

Correspondence should be addressed to Dr. Laura Lillien, Department of Neurobiology and Pittsburgh Cancer Institute, University of Pittsburgh School of Medicine, W1454 Biomedical Science Tower, Pittsburgh, PA 15261. E-mail: lillien+@pitt.edu.

Copyright $\odot 2003$ Society for Neuroscience $\quad$ 0270-6474/03/239862-11\$15.00/0
}

neurons, perhaps as many as 20-30\% (Anderson et al., 1997a). In vitro experiments revealed that cortical progenitor cells are competent to produce interneurons (Gotz and Bolz, 1994; He et al., 2001), raising questions about the reasons they fail to generate large numbers of interneurons normally during embryonic development. One possibility is that the environment in the dorsal telencephalon does not support the production of interneurons, because of the absence of inductive signals and/or the presence of inhibitory signals.

Although the intrinsic control of cortical interneuron development has been studied extensively (Anderson et al., 1997b, 1999; Casarosa et al., 1999; Sussel et al., 1999), the function of extrinsic signals in the specification of interneurons is less well established. One of the most investigated secreted morphogens, sonic hedgehog (Shh), is expressed at a high level in cells of the ventral telencephalon at embryonic day 11.5 (E11.5) and onward (Kohtz et al., 1998; Sussel et al., 1999; Nery et al., 2001; TekkiKessaris et al., 2001). Shh has been implicated in several aspects of CNS development, such as proliferation (Dahmane and Ruiz-iAltaba, 1999; Wallace, 1999; Wechsler-Reya and Scott, 1999) and cell fate determination (Marti et al., 1995; Roelink et al., 1995; Chiang et al., 1996; Ericson et al., 1996). The role of Shh in interneuron development has been suggested by studies of its impact on Dlx (Kohtz et al., 1998, 2001), which has been implicated in the specification of interneurons (Stuhmer et al., 2002). A direct 
demonstration that Shh induces interneurons was reported recently in monolayer cultures of FGF-stimulated cortical cells (Yung et al., 2002). It remains to be determined, however, whether Shh induces interneurons under more physiological conditions. Development in cortical explants more closely resembles development in vivo (Burrows et al., 1997). In the present study we used explants of E11.5 mouse telencephalon to test the hypothesis that regional differences in both inductive and inhibitory environmental signals control the production of GABAergic versus glutamatergic neurons by dorsal telencephalic progenitors.

\section{Materials and Methods}

Explant cultures. Timed-pregnant CD1 mice (Charles River Laboratories, Wilmington, $\mathrm{MA}$ ) were killed with $\mathrm{CO}_{2}$. E11.5, E13, or E16 embryos were placed in sterile HBSS (Invitrogen, Bethesda, MD), and the brains were dissected. Dorsolateral and dorsomedial walls of the telencephalon were dissected (Fig. $1 \mathrm{~A}$ ) and transferred to nucleopore filters ( $13 \mathrm{~mm}, 0.2 \mu \mathrm{m}$ pore; Corning, Fisher Scientific, Pittsburgh, PA) floating on serum-free culture medium (Bottenstein and Sato, 1979) containing $25 \mu \mathrm{g} / \mathrm{ml}$ insulin (Sigma, St. Louis, MO). For some experiments, GEs (medial and lateral) were also dissected. Approximately 25-30 min later, $30 \mu \mathrm{l}$ of culture medium containing retrovirus was added to the tops of the filters carrying dorsal telencephalic explants. This results in a selective infection of progenitor cells in the VZ (Burrows et al., 1997). Viruses included: control virus (titer: $1-2 \times 10^{7} \mathrm{cfu} / \mathrm{ml}$ ), which expresses $\beta$-galactosidase $(\beta$-gal), and dominant-negative bone morphogenetic protein receptor $\mathrm{Ib}$ (dnBMPRIb) virus (titer: $1-2 \times 10^{7} \mathrm{cfu} / \mathrm{ml}$ ), which coexpresses $\beta$-gal (Lillien and Raphael, 2000). In experiments in which Shh signaling was blocked, explants were cultured in the presence of either a Shh neutralizing monoclonal antibody (5E1) (Ericson et al., 1996) [diluted in 1:5; Developmental Studies Hybridoma Bank, (DSHB) Iowa City, IA] or different concentrations of cyclopamine $(0.5,5.0$, and $10.0 \mu \mathrm{M}$; Toronto Research Chemicals Inc., North York, Ontario, Canada). Cyclopamine at $5 \mu \mathrm{M}$ was found to be the most effective. $5 \mathrm{E} 1$ or cyclopamine was added to the culture medium daily. For controls, explants were exposed to culture supernatant containing a control antibody (anti-Pax6 antibody) (DSHB) or DMSO. In some experiments recombinant FGF2 (10 ng/ml; R \& D Systems, Minneapolis, MN), recombinant BMP4 (10 ng/ml; R \& D Systems) or unmodified recombinant Shh-N $(0.05,0.5$, or $5.0 \mu \mathrm{g} / \mathrm{ml}$; R \& D Systems) was added to cultures. After $4 \mathrm{~d}$ in culture, explants were dissociated enzymatically using $0.1 \%$ trypsin (Sigma) in calcium and magnesium-free $\mathrm{HBSS}$ for $15 \mathrm{~min}$ at $35^{\circ} \mathrm{C}$. After trituration, the dissociated cell suspensions were plated on poly-D-lysine (PDL) (Sigma)-coated glass slides $\left(1 \times 10^{5}\right.$ cells each in serum-free medium) for $1 \mathrm{hr}$ at $37^{\circ} \mathrm{C}$ before they were fixed and labeled with antibodies (see below). In some experiments, cells were dissociated after $4 \mathrm{~d}$ in explant culture then grown as a monolayer on polyornithine-coated coverslips for $3 \mathrm{~d}$ in serum-free medium before they were stained with antibodies (Fig. $1 A^{\prime}$ ). Dissociation facilitates the removal of trophic factors added to the explants (such as FGF2, Shh) and accelerates differentiation.

Aggregate cultures. Dorsomedial telencephalic wall and ganglionic eminence explants were dissected from E11.5 embryonic brains. To distinguish progenitor cells arising from the dorsomedial wall, "responding" explants (dorsomedial wall explants) were infected with control retrovirus as described above, whereas the "inducing" tissues (dorsomedial wall or GEs) remained uninfected. One day after infection, explants were dissociated enzymatically (see above), and an equal number of cells from infected and uninfected explants $\left(2-3 \times 10^{5}\right.$ total cells) were mixed in 15 $\mathrm{ml}$ conical centrifuge tubes. Centrifugation was used to form an aggregate (Watanabe and Raff, 1990), and three aggregates per condition were transferred to nucleopore filters floating on serum-free medium. After $3 \mathrm{~d}$ in culture, aggregates were dissociated and prepared for immunostaining as described for explants.

Immunocytochemistry. Dissociated cells plated on glass slides or coverslips were fixed in $4 \%$ paraformaldehyde (PFA) in $0.1 \mathrm{M}$ phosphate buffer (PB), pH 7.4, or in 4\% PFA in 3\% PIPES buffer for 10 min at room temperature. Cells were fixed with $4 \% \mathrm{PFA}$ in $0.1 \mathrm{~m} \mathrm{~PB}$ and $0.1 \%$ glutaraldehyde (Sigma) to stain with anti-GABA antibody or $4 \%$ PFA in $0.1 \mathrm{M}$
PB and 3\% glutaraldehyde to stain with monoclonal anti-glutamate antibody. After rinsing with PBS, cells were blocked in PBS containing 10\% fetal bovine serum (FBS) (Invitrogen) and 0.1\% Triton X-100. Cells were then incubated in primary antibodies for $1 \mathrm{hr}$. The following primary antibodies were used: rabbit anti- $\beta$-galactosidase $(1: 1000$; Cortex Biochem, Inc., San Leandro, CA), mouse anti- $\beta$-galactosidase (1:200; Promega, Madison, WI), mouse anti-TuJ1 (1:400; Covance Research Products, Berkeley, CA), mouse anti-PCNA (1:100; Sigma), rabbit anti-GABA (1:2000; Sigma), mouse anti-GAD6 (1:2; DSHB), rabbit anti-glutamate (1:2000; Sigma), and mouse anti-glutamate (1:2000; Chemicon, Temecula, CA). Staining was visualized with fluorescent secondary antibodies: donkey anti-mouse or anti-rabbit cy2 or cy3 (cy2: 1:200, су3: 1:800; Jackson ImmunoResearch, West Grove, PA). Secondary antibodies were applied for $30 \mathrm{~min}$ at room temperature. Finally, cells were rinsed in PBS and mounted in 95\% glycerol in PBS. Fluorescent images were obtained using a Leica (Nussloch, Germany) DMR microscope. Sensys digital camera (Photometrics Ltd., Tuscon, AZ), IPLab, and Adobe Photoshop 6.0 software (Adobe Systems Inc., San Jose, CA).

Data collection and analysis. In each experiment 100 infected cells ( $\beta$ $\mathrm{gal}+$ cells) were counted per condition per antibody, and the proportion of neurons $(\mathrm{TuJ} 1+)$, proliferating cells $(\mathrm{PCNA}+)$, excitatory neurons (glutamate + ), or interneurons (GABA+ or GAD6+) was determined. At least three experiments were performed per condition. Data are represented as mean $(\%) \pm$ SEM. To verify whether differences between distinct conditions reach the significance level $p<0.05, t$ tests were used.

Immunohistochemical staining of cortical sections. Cryostat sections $(20$ $\mu \mathrm{m}$ ) were cut from E11.5 mouse brains. After fixation with 4\% PFA in 0.1 M PBS, pH 7.4, in the presence of $0.1 \%$ glutaraldehyde (Sigma) and blocking in PBS containing 10\% fetal bovine serum (Invitrogen) and $0.1 \%$ Triton $\mathrm{X}-100$, sections were incubated in primary antibody (rabbit anti-GABA, 1:2000; Sigma) overnight at $4^{\circ} \mathrm{C}$. Sections were rinsed and incubated in secondary antibody (donkey anti-rabbit cy2, 1:200; Jackson ImmunoResearch) for $2 \mathrm{hr}$. The staining was photographed with a Leica DMR microscope using fluorescence optics.

\section{Results}

\section{Regional differences in interneuron development}

We wanted to investigate the generation of interneurons from progenitors in the dorsal telencephalic wall before the beginning of interneuron migration from the ventral telencephalon. We also wanted to determine whether there were regional differences within the dorsal telencephalon in the capacity of progenitor cells to produce interneurons. To address these issues we used explants of E11.5 mouse telencephalon comparing medial and lateral dorsal telencephalic walls. Explants were dissected as indicated in Figure $1 A$. To label proliferating cells in the dorsal telencephalic ventricular zone, progenitors in explants were infected with a retrovirus that expresses the histochemical marker $\beta$-gal (Burrows et al., 1997). The phenotypes of the progeny of virus-infected cells were determined either after acute dissociation of explants after $4 \mathrm{~d}$ in vitro (div) or after dissociation of $4 \mathrm{div}$ explants and culture as a monolayer for an additional $3 \mathrm{~d}$ (7 div total) (Fig. $1 A^{\prime}$ ). Cells were double-labeled for the lineage marker $\beta$-gal to identify the virus infected cells (Fig. $1 C, D, H, I, K, L)$ and either TuJ1, an early neuronal marker (Fig. $1 E^{\prime}, F^{\prime}, H^{\prime}, I^{\prime}$ ), GABA, a general marker for inhibitory interneurons (Fig. $1 C^{\prime}, D^{\prime}, E, F$ ), or glutamate to label projection neurons (Fig. $1 K^{\prime}, L^{\prime}$ ).

In the dorsal telencephalon, lateral wall-derived progenitor cells generated significantly more GABAergic interneurons than did progenitor cells in the medial telencephalic region after $4 \mathrm{~d}$ in explant culture (Fig. $1 \mathrm{~B}$ ). When cells from dorsomedial (DM) or dorsolateral (DL) wall explants were dissociated after 4 div and allowed to differentiate for an additional $3 \mathrm{~d}$ as monolayers ( $7 \mathrm{div}$ total) in the absence of exogenous growth factors, the proportion of interneurons was further increased, but medial-lateral differences in the generation of interneurons were still apparent (Fig. 

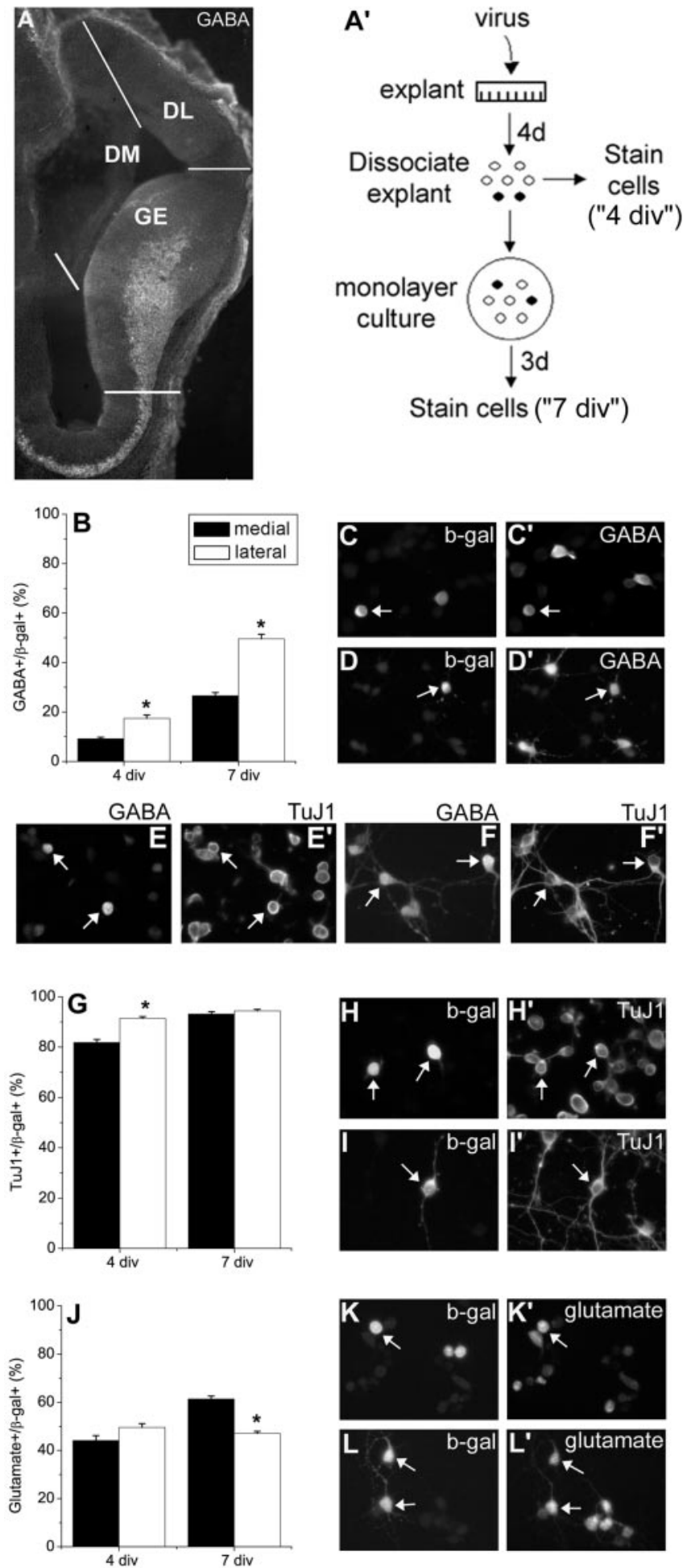

Figure 1. Dorsolateral progenitors generate more interneurons than dorsomedial progenitors in E11.5 telencephalic explants. A, Coronal sections from E11.5 mouse telencephalon were stained for GABA to show the extent of tangential migration of GABAergic neurons from the ganglionic eminences. This panel also illustrates how explants were dissected from different telencephalic regions. $A^{\prime}$, Explant cultures from E11.5 telencephalon were infected with a control retrovirus that expresses $\beta$-galactosidase. Four days later, the fate of infected cells was determined immunocytochemically $1 \mathrm{hr}$ after dissociation $\left(C, C^{\prime}, E, E^{\prime}, H, H^{\prime}, K, K^{\prime}\right)$. Some of these dissociated cells were cultured as monolayers for an additional $3 \mathrm{~d}$ ( 7 div total; $D, D^{\prime}, F, F^{\prime}$, $\left.I, I^{\prime}, L, L^{\prime}\right)$. Cultures were stained with $\beta$-gal and either the general interneuron marker GABA $\left(C^{\prime}, D^{\prime}, E, F\right)$, the early neuronal marker TuJ1 $\left(E^{\prime}, F^{\prime}, H^{\prime}, I^{\prime}\right)$, or the projection neuron marker glutamate $\left(K^{\prime}, L^{\prime}\right)$. Some of the dissociated cells were double labeled for TuJ1 and GABA at $4(E$, $\left.E^{\prime}\right)$ and $7 \operatorname{div}\left(F, F^{\prime}\right)$ to confirm that all GABA+ cells were also TuJ1+, therefore neurons.
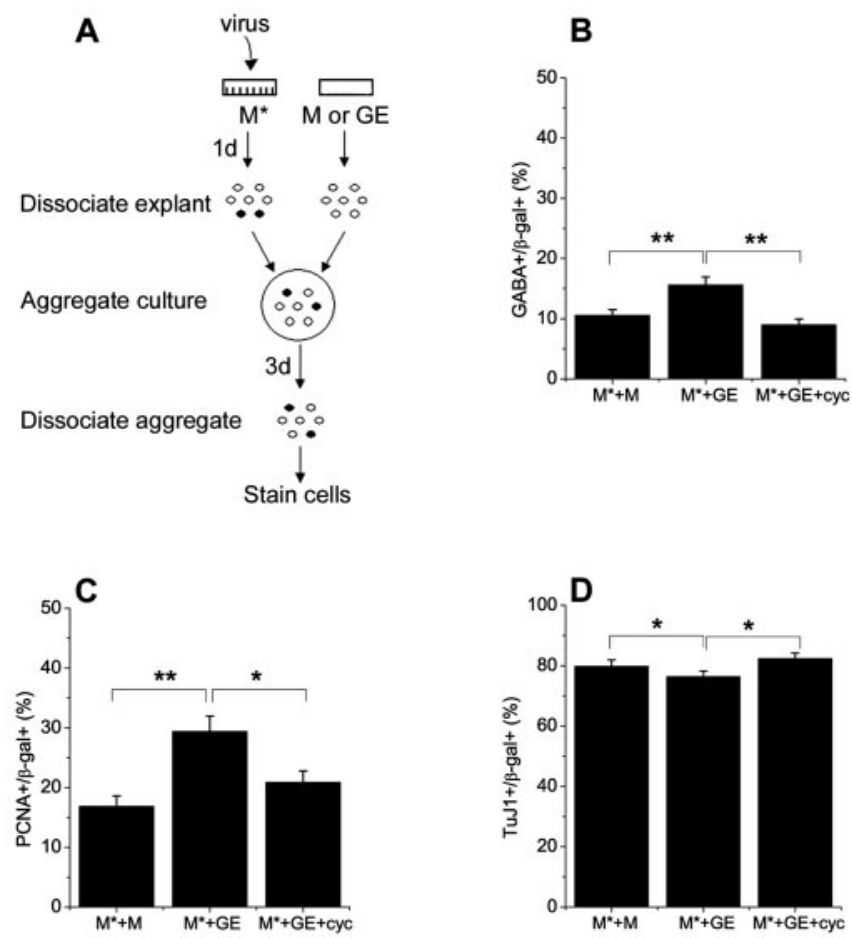

Figure 2. Ventral telencephalic cells can induce the generation of interneurons from dorsomedial progenitors via Shh. A, Schematic diagram illustrates the experimental procedure by which aggregate cultures were prepared from ganglionic eminences and dorsomedial telencephalon. $B$, The proportion of GABAergic interneurons generated by $\beta$-gal + dorsomedial progenitors was increased in cultures in which dorsomedial progenitors were cocultured with ganglionic eminence-derived cells $\left(\mathrm{M}^{*}+\mathrm{GE}\right)$, compared with the ones in which dorsomedial telencephalic cells were cultured alone $\left(M^{*}+M\right)$. Blocking Shh signaling with cyclopamine $(5$ $\mu \mathrm{M} ; \mathrm{cyc})$ diminished interneuron production induced by $\mathrm{GE}\left(\mathrm{M}^{*}+\mathrm{GE}+\mathrm{cyc}\right)$. A ventrally derived signal or signals increased the proliferation of dorsomedial progenitors $(C)$ and decreased neuronal differentiation $(D)$, suggesting that it delayed neuronal differentiation by stimulating proliferation. These effects of ventral cells were also blocked by cyclopamine. ${ }^{*} p=0.04 ;{ }^{* *} p \leq$ 0.009 .

1B). All GABA + cells were also TuJ1+ at 4 and 7 div (Fig. $\left.1 E, E^{\prime}, F, F^{\prime}\right)$. To confirm the regional difference in interneuron development, we used another well characterized marker of interneurons, GAD65 (Benson et al., 1994; Phelps et al., 1999), a synthesizing enzyme for GABA. At $7 \mathrm{div}, 89.3 \pm 1.8 \%$ of the GABA + cells were GAD $+(n=4)$. The proportion of GAD + cells among control virus-infected cells was higher laterally than medially (GAD $+/ \beta$-gal $+: 26 \pm 2.2 \%$ vs $50.3 \pm 3.5 \%$; medial vs lateral; $7 \operatorname{div} ; n=4 ; p=0.002$ ), confirming the results obtained using GABA immunostaining to identify interneurons. None of the GABAergic cells showed any level of glutamate expression at 4 or $7 \mathrm{div}$, in either the control virus-infected or the uninfected populations (glutamate $+/ \mathrm{GABA}+: 0 \pm 0 ; n=4$ ).

There was no difference in the proportion of neurons after 7 div (Fig. $1 G$ ), although DL telencephalic explants produced significantly more neurons than did DM telencephalic explants after 4 div. This might reflect more extensive proliferation in DM than

Arrows in $C, D, H, I, K$, and $L$ point to $\beta$-gal + cells that are also labeled with a cell-type marker. Arrows in $C^{\prime}, D^{\prime}, H^{\prime}, I^{\prime}, K^{\prime}$, and $L^{\prime}$ show GABA+, TuJ1+ or glutamate + cells, which are also $\beta$-gal + . Arrows in Eshow $2 \mathrm{GABA}+$ cells, which are TuJ1+ $\left(E^{\prime}\right)$. Note that many of the TuJ1+ cells $\left(E^{\prime}\right)$ are not immunoreactive for GABA $(E)$. In $F$, arrows point to two of the five GABA+ cells, and $F^{\prime}$ indicates that these cells are also TuJ $1+{ }^{*} p<0.0001$, comparing dorsolateral progenitors to dorsomedial progenitors. 
in DL telencephalic explants at $4 \operatorname{div}(18.5 \pm 1.4$ vs $8.5 \pm 0.5 \%$; DM vs DL; $n=10 ; p<0.0001$ ), which delayed neuronal differentiation medially. Analyzing the production of glutamatergic neurons revealed a complementary difference in their development compared with GABAergic neurons. By 7 div more glutamatergic neurons were produced from DM-derived progenitors than from DL ones (Fig. $1 \mathrm{~J}$ ). None of the glutamatergic neurons were GABA+ $(\mathrm{GABA}+$ /glutamate $+: 0 \pm 0 ; n=3)$.

To determine whether the potential of dorsal telencephalic progenitor cells to generate interneurons is restricted to certain developmental stages, we analyzed DM and DL telencephalic explants from E13 and E16 embryonic brains after 4-7 div. We did not observe an age-related decline in the competence of dorsal telencephalic progenitor cells to produce interneurons. Moreover, more GABAergic neurons were produced from late progenitors than from early ones. For example, when progenitor cells were labeled by control virus infection at E13, 38.8 $\pm 5.7 \%$ of DM progenitors generated GABA + neurons after 7 div, compared with $26.6 \pm 1.3 \%$ of E11.5 progenitors $(p=0.004)$. E13 DL progenitors also produced a high proportion of interneurons after $7 \operatorname{div}(55.7 \pm 11.6 \%)$. Even at E16, $26 \pm 1.8 \%$ of DL telencephalic wall progenitors expressed GABA after $4 \mathrm{~d}$ in explant cultures.

\section{Ventral telencephalon enhances production of interneurons by DM telencephalic progenitors}

The fact that DL telencephalic progenitors generated more interneurons than their medial counterparts raised the possibility that GEs, which are closer to DL cortex, produce a signal that promotes the development of interneurons in the adjacent dorsal telencephalon. To determine whether ventral telencephalic signals can modulate the production of interneurons by dorsal telencephalic progenitors, aggregates were formed from cells derived from DM telencephalic explants and GEs (Fig. 2A).

Progenitor cells from the medial wall of the dorsal telencephalon were labeled with control retrovirus, whereas GE cells were not infected. When E11.5 DM wall cells were mixed with cells from GEs, we found that there was a 1.5-fold increase in the proportion of GABAergic neurons generated by DM progenitors compared with progenitors in aggregates of DM wall alone (Fig. $2 B$ ). This provided further support for the idea that local environmental cues, rather than limited potential of progenitors, are responsible for the low production of interneurons in the DM telencephalon under normal circumstances.

\section{Blocking Shh signaling inhibits the interneuron-inducing effect of the ventral telencephalon}

After observing that ventral telencephalon could promote interneuron development by DM telencephalic progenitors, we wanted to identify the factor or factors that could be responsible for this effect. Shh is a good candidate for mediating interneuron development for several reasons. First, it is highly and specifically expressed in ventral telencephalon early in development (E11 and onward) (Kohtz et al., 1998; Sussel et al., 1999; Nery et al., 2001; Tekki-Kessaris et al., 2001). Second, cortical explants cultured in the presence of Shh start to express Dlx genes (Kohtz et al., 1998), which are believed to be essential for interneuron development (Stuhmer et al., 2002). Third, Shh has been shown to increase the number of clones that contain GABAergic neurons in cultures of FGF-expanded cortical progenitors (Yung et al., 2002).

To determine whether the interneuron-inducing effect of the ventral telencephalon in aggregate cultures was mediated by Shh, we blocked Shh signaling in these cultures. One day after aggregates were formed from E11.5 DM telencephalic and GE cells, 5 $\mu \mathrm{M}$ cyclopamine was added to cultures to block Shh signaling. Cyclopamine blocked the induction of interneurons by ventral telencephalic cells (Fig. 2 B). This provides further support for the idea that Shh produced by the ventral telencephalon promotes the development of interneurons in the dorsal telencephalon. Cyclopamine also inhibited proliferation of DM wall progenitors induced by GE in aggregates (Fig. 2C), and increased the proportion of neurons to the level seen in cultures of DM alone (Fig. 2D).

\section{Blocking endogenous Shh signaling in the dorsal telencephalon inhibits interneuron development}

The experiments above demonstrated that ventral telencephalon can promote the development of interneurons from DM telencephalic progenitor cells, and that the induction depended on Shh. Shh is expressed in the dorsal telencephalon by E14 (Dahmane et al., 2001). At earlier stages of development, it has been reported that Shh may be expressed ectopically in explants of dorsal telencephalon (Tekki-Kessaris et al., 2001). It is also possible that Shh produced by ventral telencephalon diffuses into more dorsal regions of the telencephalon even at early stages of development (Incardona et al., 2000; Zeng et al., 2001). To determine whether "endogenous" Shh signaling contributes to interneuron development in DL cortex, E11.5 DL explants were cultured in the absence or presence of cyclopamine (Cooper et al., 1998; Incardona et al., 1998) or an Shh-neutralizing antibody (Ericson et al., 1996). When Shh signaling was blocked with cyclopamine (5 $\mu \mathrm{M})$, the proportion of GABAergic neurons in the DL telencephalon was reduced at 4 and 7 div (Fig. $3 A$ ). A similar effect was observed with Shh neutralizing antibody $(17.3 \pm 2.6$ vs $11.0 \pm$ 1.7\%; control antibody vs anti-Shh antibody; after 4 div; $n=4$; $p=0.02)$. Cyclopamine also reduced the generation of interneurons in DM telencephalic explants $(9.3 \pm 0.9$ vs $6.0 \pm 0.6 \%$; DMSO vs cyclopamine; 4 div; $n=4 ; p=0.007)$. When Shh was blocked, we noted a complementary increase in glutamatergic neurons compared with interneurons at 4 and 7 div in DL explants (Fig. 3B). Blocking Shh signaling also caused a decrease in proliferation (Fig. 3C), as reported by Dahmane et al. (2001), but it did not lead to a significant difference in the proportion of neurons at 4 and 7 div (Fig. 3D). These results imply that Shh signaling is involved in the development of interneurons in the dorsal telencephalon and may regulate the relative proportion of inhibitory and excitatory neurons.

\section{Exogenous Shh can enhance interneuron generation by dorsomedial progenitors}

The regional difference in interneuron development that we observed in the dorsal telencephalon is consistent with the idea that ventral telencephalic cells produce an inductive signal, most likely Shh, and the proximity of DL cortex to the source of this positive signal causes DL progenitors to produce more interneurons than their medial counterparts. Our results above suggested that DL cortex contained endogenous Shh, because adding cyclopamine to DL explant cultures could diminish the production of interneurons. This is also consistent with a previous study showing the presence of Shh in E13.5 cortical explants (Tekki-Kessaris et al., 2001). If an insufficient level of Shh signaling is what prevents DM progenitors from becoming interneurons with a higher frequency, then adding exogenous Shh to DM wall explants should increase the probability that DM progenitors generate interneurons.

To address whether exogenous Shh can mimic the 
interneuron-inducing effect of ventral telencephalon, DM telencephalic explants were dissected, and recombinant Shh was added to the cultures at different concentrations: $0.05,0.5$, and $5 \mu \mathrm{g} / \mathrm{ml}$. Shh at a concentration of 0.5 or $5.0 \mu \mathrm{g} / \mathrm{ml}$ increased the percentage of GABAergic interneurons after $4 \mathrm{~d}$ in explant culture (Fig. 3E). It also stimulated proliferation (Fig. $3 G$ ), as reported by Rowitch et al. (1999), raising questions about the ultimate fate of the dividing cells. Shh-treated progenitors still generated more interneurons than untreated cultures after 7 div (Fig. 3E). A significant increase in GABA+ cells was also apparent in cultures treated with $0.05 \mu \mathrm{g} / \mathrm{ml}$ Shh as explants (after 7 div: $24.8 \pm 0.8 \%$ vs $39.5 \pm 3.5 \%$; untreated vs Shh-treated; $n=4 ; p=0.01$ ). The percentage of neurons was not altered after 7 div (Fig. $3 H$ ); however, there was a complementary reduction in glutamatergic neurons in the Shh-treated cultures (Fig. 3F). These data support the idea that Shh promotes the development of interneurons and that Shh levels in the DM telencephalon are suboptimal for interneuron generation.

\section{BMP inhibits interneuron generation from dorsolateral telencephalic progenitor cells}

Although a limiting concentration of Shh in the dorsal telencephalon, particularly the DM region, could account for regional differences in interneuron development, inhibitors in the DM wall could also be involved in regulation of interneuron differentiation. BMPs are normally expressed at higher levels in the DM wall (Furuta et al., 1997; Grove et al., 1998) and antagonize Shh signaling in many tissues (Ericson et al., 1995; Liem et al., 1995; Watanabe et al., 1998; Zhu et al., 1999). To test the effect of BMP on interneuron development, DL telencephalic explants were dissected from E11.5 mouse brains, and BMP4 was added to the cultures. Application of BMP4 decreased the proportion of interneurons at 4 and 7 div (Fig. 4A). There was also a decrease in proliferation after treatment with BMP4 (Fig. 4B), as reported by others (Kalyani et al., 1998; Mabie et al., 1999; Zhu et al., 1999), although neuronal differentiation was not altered (Fig. 4C). These results suggest that increasing the level of BMP in the DL telencephalon causes DL progenitors to behave more like DM progenitors with respect to interneuron generation. This supports the idea that a dorsomedially derived inhibitor sup-

\section{Dorso-lateral}
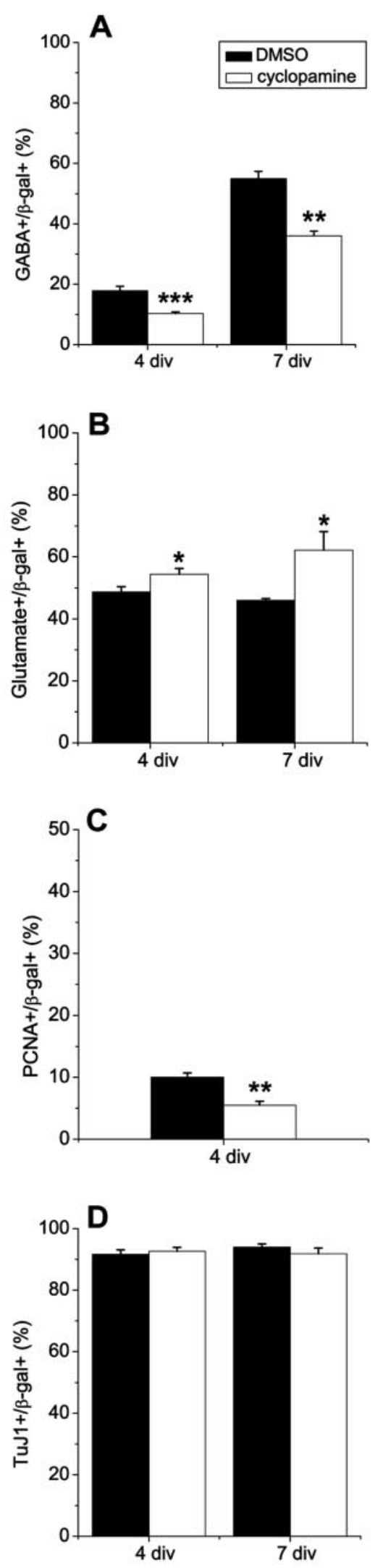

Dorso-medial
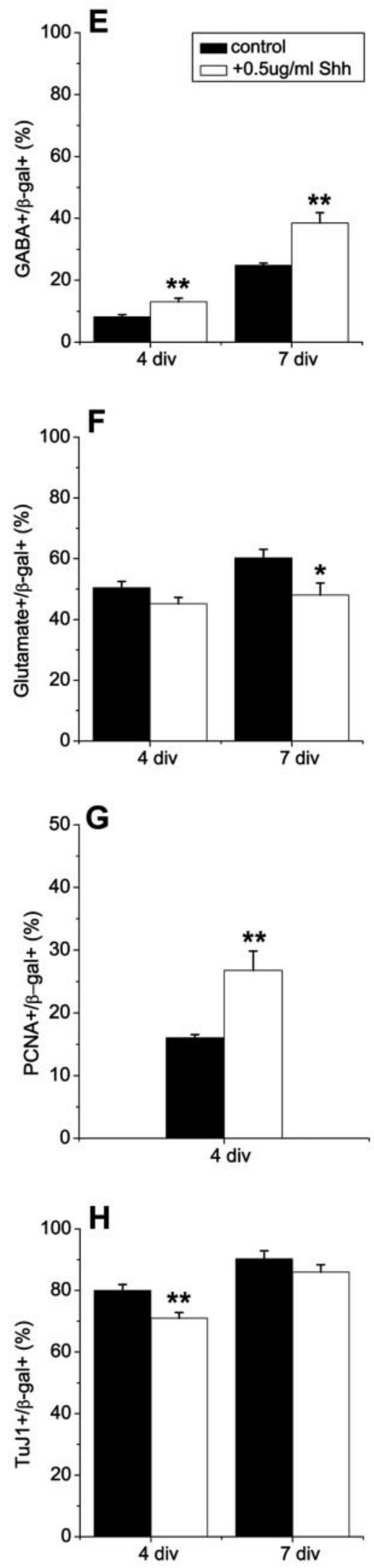
presses interneuron development in the dorsal telencephalon. When Shh was added to DM telencephalic explants, it could overcome this inhibition; however, when BMP4 was added together with Shh (Shh+BMP), BMP inhibited the inductive effect of Shh (Fig. 4D). This implies that the balance between Shh and BMP4 concentrations determines the proportion of interneurons generated.

\section{Blocking BMP signaling increases the generation of GABAergic interneurons from dorsomedial telencephalic progenitor cells}

To confirm that the DM signal that limits interneuron development normally is BMP, DM telencephalic explants were dissected from E11.5 embryos and infected with a retrovirus transducing dominant-negative BMPRIb (dnBMPRIb) and $\beta$-gal (Lillien and Raphael, 2000) or control virus. DnBMPRIb and control retrovirus-infected explants were cultured for $4 \mathrm{~d}$ before they were dissociated and either processed for immunocytochemistry or allowed to differentiate for 3 more days ( 7 div total). In acutely dissociated explant cultures there was no significant difference in the proportion of interneurons between control and dnBMPRIbinfected cells, however when these cells were allowed to differentiate further, dnBMPRIb-infected cells produced considerably more GABAergic interneurons than control virus-infected cells (Fig. 5A). A comparable difference between control and dnBMPRIb virus-infected DM cells was observed using GAD antibody to distinguish interneurons $(\mathrm{GAD}+/ \beta$-gal $+: 26 \pm 2.2 \%$ vs $51 \pm 4.6 \%$; control vs dnBMPRIb virus; 7 div; $n=4 ; p=0.002$ ). In contrast to DM progenitors, when DL progenitors were infected with dnBMPRIb or control virus, we could not see a significant increase in the proportion of interneurons generated from dnBMPRIb-infected progenitors $(39.3 \pm 3.2$ vs $46.0 \pm$ $3.8 \%$; control virus vs dnBMPRIb virus; $7 \mathrm{div} ; p=0.25)$. This observation further supports the idea that an interneuroninhibiting signal is most abundant or active in the DM telencephalon. As noted previously, dnBMPRIb virus increased proliferation (Fig. 5B) (Lillien and Raphael, 2000) and reduced differentiation into neurons in explant culture at 4 div (Fig. 5C). However, after the dissociated cells differentiated for 3 more days (7 div total) in the absence of exogenous mitogens, the proportion of neurons generated from dnBMPRIb-infected cells approached that seen in control-infected cultures (Fig. 5C). The percentage of glutamatergic neurons was reduced among cells infected with dnBMPRIb virus (Fig. 5D), suggesting a complementary change in interneurons and projection neurons. These observations further support the idea that endogenous BMPs normally inhibit the production of interneurons in the dorsal telencephalon, particularly in the DM wall.
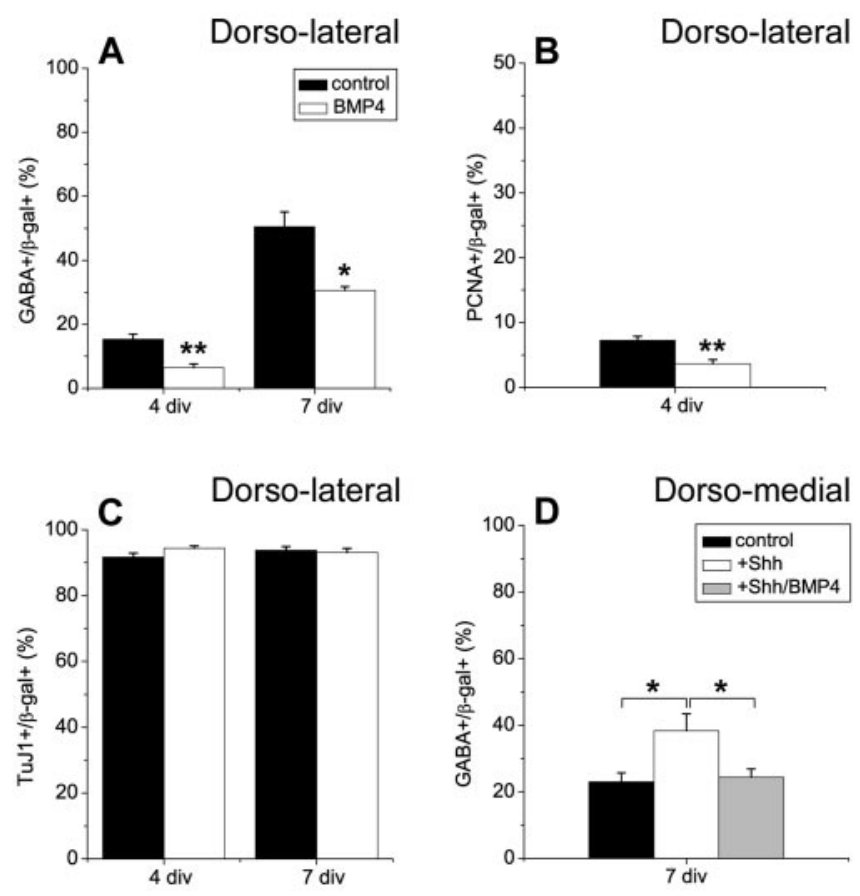

Figure 4. BMP4 inhibits the generation of interneurons. $A-C$, Dorsolateral telencephalic explants were infected with control virus expressing $\beta$-gal at $E 11.5$ and cultured in the absence or presence of BMP4 $(10 \mathrm{ng} / \mathrm{ml})$ for $3 \mathrm{~d}$ (4 div total). After 4 div the proportion of $\mathrm{GABA}+(A)$, PCNA + $(B)$, or TuJ1 + ( $C$ cells was determined among the virus-infected, $\beta$-gal + cells. Cells from dissociated explants were also cultured as monolayers for $3 \mathrm{~d}$ without BMP4 (7 div total). Dorsolateral telencephalic progenitors generated fewer interneurons $(A)$, approximately equal proportions of neurons $(C)$, and divided less extensively $(B)$ after explants were treated with BMP4 compared with untreated explants. D, E11.5 dorsomedial telencephalic explants were infected with control virus and cultured in Shh alone $(0.5 \mu \mathrm{m})$ or Shh + BMP4 $(0.5 \mu \mathrm{m}$ Shh; 10 $\mathrm{ng} / \mathrm{ml}$ BMP4) for $3 \mathrm{~d}$ (4 div total). Explants were dissociated, cultured as monolayers without exogenous factors, and the proportion of GABAergic neurons was determined $3 \mathrm{~d}$ later (7 div total). Shh alone induced the production of interneurons, but BMP4 inhibited the interneuroninducing effect of Shh. ${ }^{*} p \leq 0.03 ;{ }^{* *} p \leq 0.0006$

\section{Proliferation does not regulate interneuron production}

Experiments modifying BMP or SHH signaling suggested a correlation between changes in the proportion of proliferating cells and in the proportion of interneurons generated: BMPs decreased proliferation and also reduced interneurons, whereas Shh and dnBMPRIb had mitogenic effects on telencephalic progenitor cells and increased interneuron development. These observations raised the possibility that increased proliferation is responsible for the increase in interneurons. The proliferation stimulating effect of fibroblast growth factor 2 (FGF2) is well documented (Gensburger et al., 1987; Tao et al., 1996; Cavanagh et al., 1997; Raballo et al., 2000), therefore we wanted to test whether adding exogenous FGF2 to dorsal telencephalic cultures would also induce interneurons. FGF2 (10 $\mathrm{ng} / \mathrm{ml}$ ) was added to DM or DL telencephalic explants, and the proportion of total neurons, interneurons, and glutamatergic neurons was determined either after $4 \mathrm{~d}$ in explant culture or $3 \mathrm{~d}$ after dissociation and culture of cells as a monolayer in the absence of exogenous FGF2 (7 div total). In DM and DL wall explants, FGF2, like Shh, increased proliferation (Fig. $6 A, B)$. Unlike Shh, however, FGF2 did not
Figure 3. Shh regulates the generation of interneurons from dorsal telencephalic progenitors. E11.5 dorsolateral and dorsomedial telencephalic explants were infected with control retrovirus expressing $\beta$-gal. $A$, The proportion of infected cells in the dorsolateral wall that expressed GABA decreased in the presence of cyclopamine $(5 \mu \mathrm{M})$, an inhibitor of Shh signaling. Cyclopamine was added to explants for $3 \mathrm{~d}$ ( 4 div total). Explants were dissociated and cultured for 3 more days as monolayers without cyclopamine (7 div total). $B$, A complementary increase in glutamatergic neurons was observed when cyclopamine was added to explants. C, Blocking Shh also decreased proliferation, but did not cause a significant change in the proportion of neurons (D). Adding recombinant Shh to dorsomedial telencephalic explants for $3 \mathrm{~d}$ ( 4 div total) increased the generation of interneurons $(E)$. Exogenous Shh reduced neuronal differentiation at $4 \operatorname{div}(H)$, which might be caused by increased proliferation $(G)$. Cells from dissociated explants were also cultured as monolayers for $3 \mathrm{~d}$ without $\operatorname{Shh}$ ( $7 \mathrm{div}$ total). The proportion of interneurons was still greater in cultures that had been exposed to Shh $(E)$. The proportion of neurons was not different after $7 \mathrm{div}$, but the production of glutamatergic neurons showed a complementary decrease compared to GABAergic neurons in Shh-treated cultures $(F) .{ }^{*} p=$ $0.04 ;{ }^{* *} p \leq 0.008 ;{ }^{* * *} p=0.0003$ 


\section{Dorso-medial}
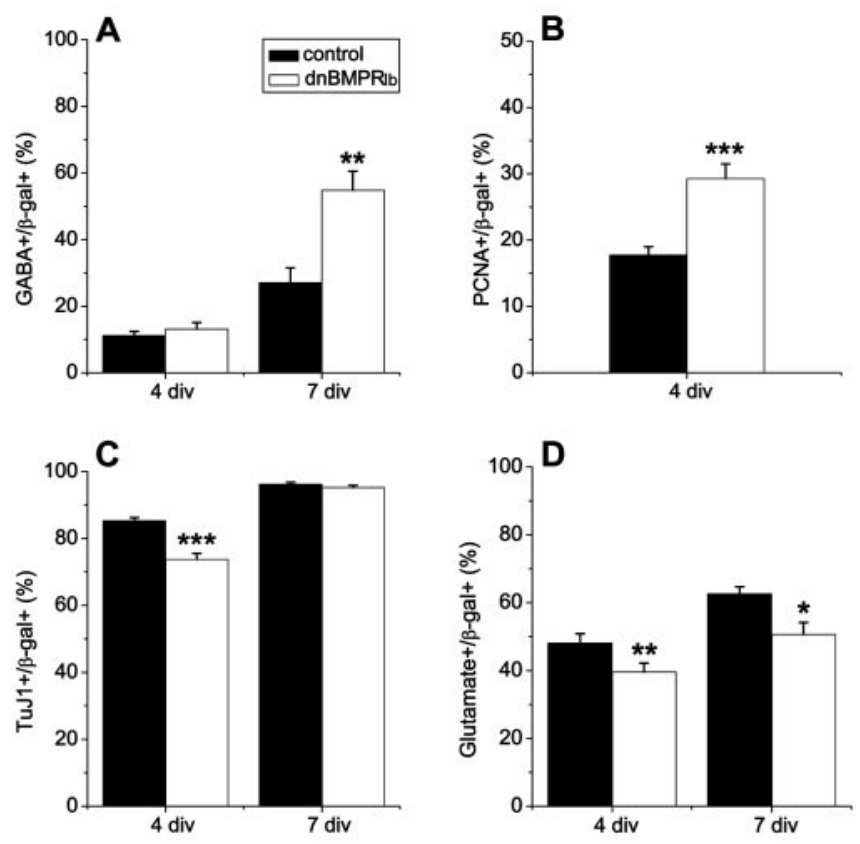

Figure 5. Blocking BMP signaling promotes the production of interneurons. Dorsomedial telencephalic progenitors were infected with control $(\beta$-gal) or dnBMPRIb (coexpressing $\beta$-gal) retrovirus at E11.5, and their progeny were analyzed after 4 and 7 div. Blocking BMP in dorsomedial progenitors caused a remarkable increase in interneuron differentiation after $7 \mathrm{div}$ $(A)$, together with a complementary decrease in the percentage of glutamatergic neurons $(D)$. $B$, Blocking BMP increased proliferation after 4 div in explants. C, Neuronal differentiation was initially reduced if BMP was blocked, consistent with increased proliferation. At 7 div, however, the percentage of neurons among dnBMPRlb and control virus-infected cells was not different. ${ }^{*} p<0.05 ;{ }^{* *} p \leq 0.005 ;{ }^{* * *} p \leq 0.0009$.

increase the production of interneurons from DM progenitors after 4 or 7 div (Fig. 6C). In explants of DL wall, FGF2 actually reduced the production of interneurons (Fig. 6D) and increased the generation of glutamatergic neurons after $7 \mathrm{div}$ (Fig. $6 F$ ). We did not observe a change in the proportion of glutamatergic neurons generated from DM progenitors (Fig. 6E). Neuronal differentiation was reduced in both DM and DL explants after 4 div, presumably because of the increase in proliferation that delayed differentiation. After 7 div a small reduction in neurons was still observed in DL but not DM explants (Fig. 6G,H). These results indicate that proliferation per se does not control the generation of interneurons.

\section{DnBMPRIb does not act via Shh to regulate interneuron production}

In a previous study, we showed that blocking BMP signaling by infection with a dnBMPR $1 b$ virus promoted the maturation of VZ progenitors to a subventricular zone (SVZ) state by a cell nonautonomous mechanism (Lillien and Raphael, 2000). We recently showed that this effect of dnBMPRIb virus was mediated by Shh (Viti et al., 2003). To determine whether Shh mediates the effect of dnBMPRIb virus on interneuron development, we added cyclopamine to block Shh in explants of DM telencephalon infected with dnBMPRIb virus. In contrast to regulation of SVZ development, Shh does not appear to mediate the effect of dnBMPRIb virus on interneuron development. For example, the proportion of GABA + cells induced by blocking BMP was not reduced when Shh was blocked simultaneously in DM telence-
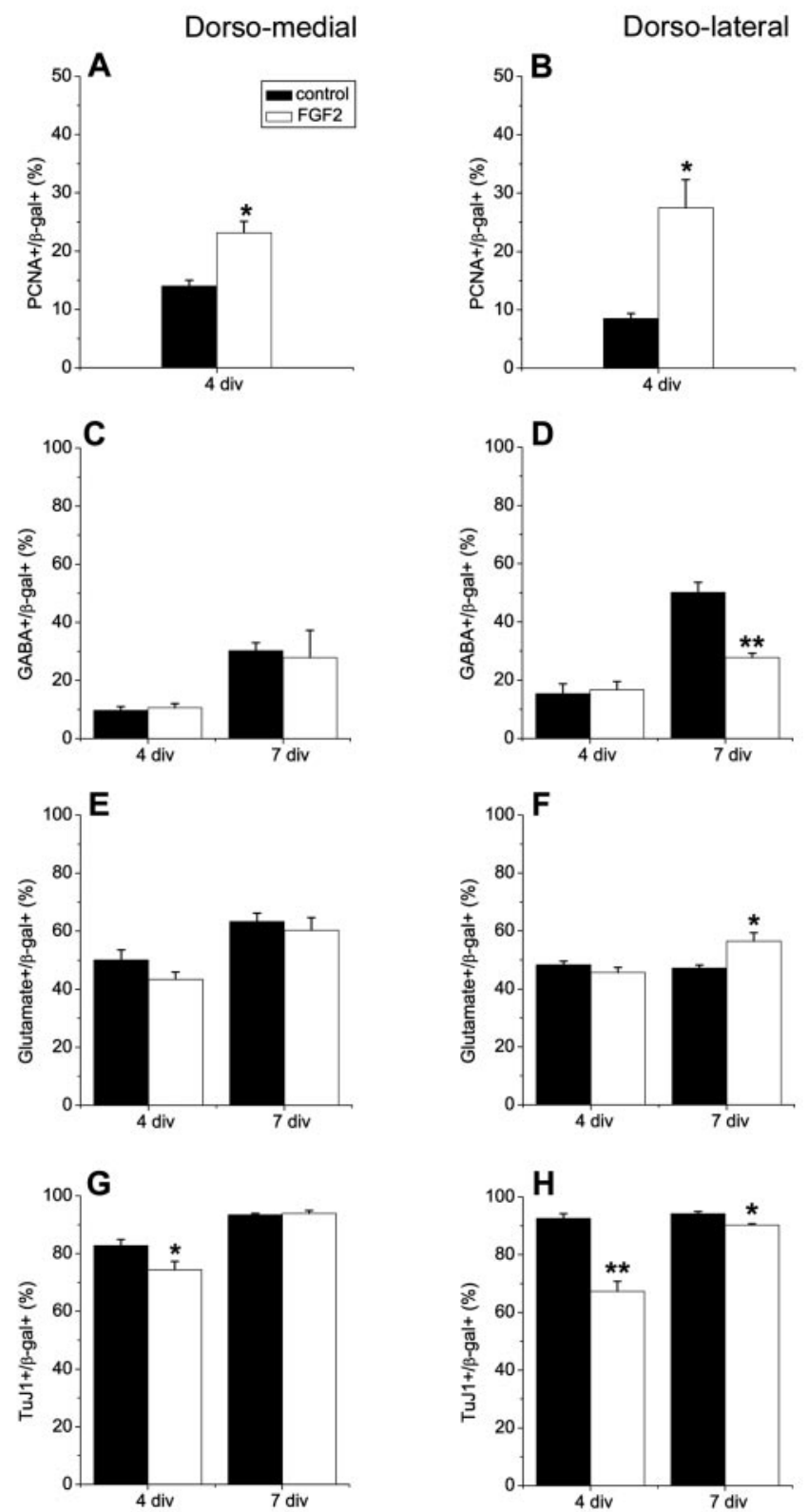

Figure 6. FGF2 does not induce interneurons in explant cultures. Progenitor cells from E11.5 dorsomedial (DM) and dorsolateral (DL) telencephalic walls were infected with a control retrovirus, cultured as explants in the absence or presence of FGF2 ( $10 \mathrm{ng} / \mathrm{ml}$ ) for $3 \mathrm{~d}$ ( 4 div total), and the proportions of proliferating cells, interneurons, projection neurons, and total neurons were determined (4 div). Explants were also dissociated and cultured for an additional $3 \mathrm{~d}$ in monolayer cultures in the absence of FGF2 (7 div total). FGF2 did not induce interneurons in DM telencephalic explants $(C)$ and decreased interneuron development in DL telencephalic explants after $7 \mathrm{div}(D)$. Neuronal differentiation was reduced in both DM and DL explant cultures at 4 div after treatment with FGF2 $(G, H)$, probably because of increased proliferation in these cultures $(A, B)$. A small decrease in the percentage of neurons was maintained in FGF2-treated DL cells after 7 div, but not in DM cells $(H, G)$. FGF2 promoted development of glutamatergic neurons in DL, but not in DM cultures $(E, F) .{ }^{*} p<0.05 ;{ }^{* *} p \leq 0.005$.

phalic explants (Fig. 7A). Blocking Shh did eliminate the transient reduction in neurons seen at 4 div among dnBMPR1binfected cells (Fig. $7 B$ ) and reduction in glutamatergic neurons (Fig. 7C). The absence of a reduction in interneurons when BMP and Shh signaling were blocked simultaneously suggests that BMP might inhibit the development of interneurons nonautonomously by blocking an as yet unidentified signal that, like Shh, 


\section{Dorso-medial}
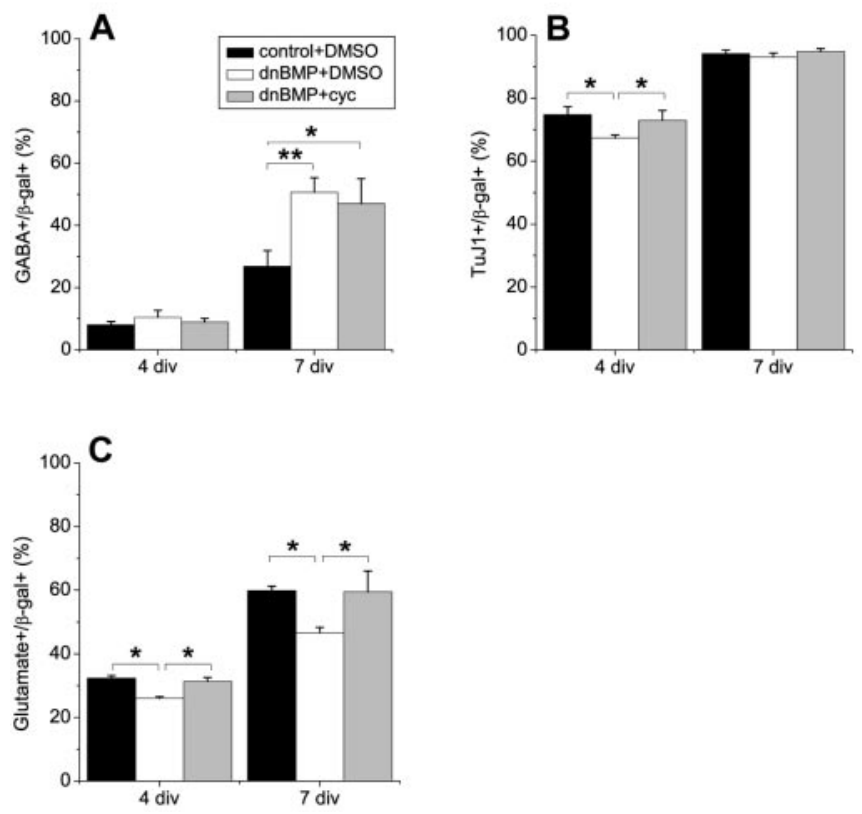

Figure 7. Blocking BMP does not stimulate interneuron generation via Shh. E11.5 dorsomedial telencephalic explants were infected with dnBMPRIb or a control retrovirus and cultured in the absence or presence of cyclopamine $(5 \mu \mathrm{m})$ for $3 \mathrm{~d}$ ( 4 div total). Explants were dissociated and cultured for $3 \mathrm{~d}$ as monolayers (7 div total). The phenotype of infected cells was analyzed after 4 and 7 div. A, Blocking BMP promoted the generation of interneurons, but blocking Shh simultaneously could not diminish this increase. Inhibiting BMP reduced the proportion of neurons after $4 \operatorname{div}(B)$ and the proportion of glutamatergic neurons $(C)$. The effects of the BMP block on total neurons and glutamatergic neurons were inhibited by cyclopamine, unlike the effect of BMP block on interneuron generation. ${ }^{*} p<0.05 ;{ }^{* *} p=0.0001$.

can promote interneuron development. Alternatively, BMP might act cell-autonomously to block the production of interneurons.

\section{Discussion}

In vivo studies indicated that most interneurons in rodents are generated in the ventral telencephalon, although they left open the possibility that some interneurons originate from dorsal telencephalic progenitors (Anderson et al., 1997a). Studies in vitro have demonstrated that dorsal progenitors are competent to generate interneurons. In the present study we addressed the possible mechanisms underlying the disparity between in vitro competence and in vivo behavior. We demonstrate that Shh can induce interneuron development in explants of dorsal telencephalon. Moreover, endogenous BMPs inhibit the generation of interneurons dorsally. Shh is predominantly expressed in the ventral telencephalon, whereas the highest expression of BMPs is observed dorsally. These findings suggest that an insufficient level of Shh and/or the inhibitory effect of BMPs normally reduce the probability that dorsal telencephalic progenitors become interneurons.

\section{Shh promotes interneuron development from dorsal telencephalic progenitors}

Several lines of evidence support the idea that Shh promotes the production of interneurons in the telencephalon. First, early in development Shh is expressed specifically by ventral telencephalic cells (Kohtz et al., 1998; Nery et al., 2001). In vivo at this developmental stage GABAergic interneurons are localized to the ventral telencephalon (Fig. $1 A$ ), therefore Shh expression and the site of interneuron development colocalize. Second, in aggregate cultures of E11.5 DM and ventral telencephalon, ventral cells induce interneuron development from dorsal progenitors, and this can be blocked by cyclopamine (Fig. 2 B). Third, if recombinant Shh is added to E11.5 cortical explants, it can mimic the interneuron- inducing effect of the ventral telencephalon (Fig. $3 E$ ). This is consistent with the findings of a recent publication in which Shh was shown to promote interneuron development in monolayer cultures of FGF2-treated cortical progenitors (Yung et al., 2002).

Shh expression is not restricted to ventral regions of the CNS, becoming apparent in the dorsal telencephalon around E14 (Dahmane et al., 2001). In explant cultures dissected from E11.5E16 dorsal telencephalon, progenitors gave rise to a significant proportion of GABAergic interneurons. This could be caused by the ectopic expression of Shh in E11.5 explant cultures (Alberta et al., 2001; Tekki-Kessaris et al., 2001), although Shh could be present at later ages (Dahmane et al., 2001). If Shh is present in the dorsal telencephalon later in development and it can promote interneuron development, one would expect that at least late cortical progenitors might give rise to interneurons. Several observations support this possibility. For example, Letinic et al. (2002) showed that in organotypic slice cultures of human embryonic forebrain, cortical VZ/SVZ cells could differentiate into interneurons, and it has been suggested that a subpopulation of interneurons that expresses calretinin might arise from the cortical SVZ at later stages of embryonic mouse development (Xu et al., 2003).

If early cortical progenitors do not generate interneurons normally, but later gestation and early postnatal progenitors may give rise to interneurons (Xu et al., 2003), it raises the possibility that progenitor maturation is involved in interneuron development. A recent study from our laboratory demonstrated that Shh could promote the maturation of VZ progenitors to an SVZ state, characterized by expression of a higher level of EGFRs among a subset of progenitors (Viti et al., 2003). One possibility is that Shh induces interneurons in the dorsal telencephalon by promoting the VZ-SVZ transition via EGFR induction and biases SVZ progenitors toward generating GABAergic interneurons. FGF2 also promotes the development of an EGFR + subset of progenitors (Lillien and Raphael, 2000). FGF2, however, does not increase the development of interneurons from dorsal telencephalic progenitors in our hands (Fig. 6C,D). It is not known whether FGF2- and Shh-induced SVZ progenitors differ in their potential to give rise to neurons versus glial cells or to subtypes of neurons. It is possible that FGF2-induced SVZ progenitors are biased to become projection neurons or astrocytes (Levison and Goldman, 1993; Tarabykin et al., 2001; Tramontin et al., 2003), whereas Shhinduced SVZ progenitors are biased to generate interneurons or oligodendrocytes (Orentas et al., 1999). It is also possible that EGFR + cells are not obligatory precursors of interneurons, because interneuron induction could be elicited at lower concentrations of Shh than upregulation of EGFR expression (A. Gulacsi, unpublished observations). The relationship between EGFR expression and interneuron generation remains to be clarified, but it should be noted that progenitors in the rostral migratory stream that give rise to olfactory bulb interneurons express a high level of EGFRs (Eagleson et al., 1996; Doetsch et al., 2002).

It has been shown that most if not all cortical interneurons express Dlx (Anderson et al., 1997b; Letinic et al., 2002) and that expression of Dlx genes in the dorsal telencephalon can induce GAD65 expression, characteristic of interneurons (Stuhmer et al., 2002). Shh was shown to induce Dlx expression in the dorsal 
telencephalon, however there was a temporal restriction in the competence of dorsal progenitors to exhibit this response to Shh (Kohtz et al., 1998). It is unlikely, however, that dorsal progenitors lose their capacity to generate interneurons during embryonic development. For example, we found that progenitors from E13 and E16 cortical explants can still differentiate into interneurons. The competence of later progenitors to produce interneurons is also consistent with their derivation from SVZ progenitors (Xu et al., 2003).

Several studies of Shh misexpression in the dorsal domain of the CNS have shown that Shh induces oligodendrocytes (Poncet et al., 1996; Pringle et al., 1996; Orentas et al., 1999). For example, when mouse embryos were infected with a Shh-expressing retrovirus at E9.5, the majority of infected cells became oligodendrocytes by postnatal day 21 (P21) (Nery et al., 2001). A general decrease in neurons was also observed, however the subtypes of neurons were not reported. The results of that study could be interpreted to suggest that Shh does not induce interneurons in vivo in the dorsal telencephalon. An alternative interpretation, however, is that during the 4 week interval between injection and analysis, oligodendrocyte progenitors may have divided more extensively than those of interneurons, masking an effect of Shh on interneurons.

\section{BMPs normally suppress interneuron development}

BMP4 is expressed in the dorsomedial telencephalon (Furuta et al., 1997; Mehler et al., 1997), although BMP4 immunoreactivity has also been detected in the lateral telencephalic wall (Li et al., 1998). In many tissues BMPs antagonize responses to Shh (Ericson et al., 1995; Mekki-Dauriac et al., 2002), therefore they represent a reasonable candidate for inhibiting interneuron generation dorsally. Our study shows that exogenous BMP4 decreases interneuron development from dorsal progenitors and antagonizes their induction by Shh (Fig. $4 A, D$ ), while blocking endogenous BMP signaling with a virus expressing dnBMPRIb increases the generation of interneurons (Fig. $5 A$ ). The inhibitory effect of BMP contradicts a recent study in which it was found that BMP and Shh interact cooperatively to promote interneuron specification (Yung et al., 2002). In that study Shh and BMP2 were added to monolayer cultures of FGF2-primed E12.5 cortical progenitors. In contrast, we used explant cultures, in which cellcell interactions are maintained, as in the in vivo environment. Moreover, our cultures were not primed with FGF2, which can alter properties of progenitors (Lillien and Raphael, 2000). These differences in culture preparations might account for the difference in the effect of BMP on interneurons we observed.

\section{How might extrinsic factors act to regulate interneuron development?}

Several mechanisms could underlie the regulation of interneuron development by Shh and BMP. For example, Shh could promote interneuron generation by suppressing the inhibitory effect of BMPs (Fig. 4D). Shh has been shown to antagonize BMP signaling at several levels (Zhu et al., 1999; Mekki-Dauriac et al., 2002). FGF2 has also been shown to antagonize BMP signaling in other systems as well as in embryonic cortex (Lillien and Raphael, 2000; Anderson et al., 2002). If just inhibiting BMP signaling was sufficient to induce interneurons, then FGF should mimic the effect of Shh on interneuron development. Our findings showed that this is not the case.

An alternative mechanism to explain the antagonistic effect of BMP and Shh on interneuron development is that generation of interneurons is regulated by proliferation. BMPs inhibit prolifer- ation, whereas blocking BMP signaling or adding Shh stimulates proliferation, and these changes in proliferation are correlated with changes in the percentage of interneurons. FGF2 also stimulates proliferation but it does not promote the generation of interneurons, therefore a proliferation-based mechanism is not likely.

Shh was recently shown to maintain the survival of neuroepithelial cells by preventing Ptc-1-induced apoptotic cell death (Thibert et al., 2003). It is not likely that changes in interneuron generation were attributable to the selective survival or death of interneurons, because changes in interneurons were usually coupled to complementary changes in glutamatergic neurons, and the overall number of neurons was not altered.

We showed previously that blocking BMP signaling with a dnBMPRIb virus promoted the development of EGFR+ SVZ progenitors via Shh (Lillien and Raphael, 2000; Viti et al., 2003). In contrast, in the present study we found that Shh does not mediate interneuron development induced by blocking BMP with dnBMPRIb (Fig. 7A). This suggests that BMP does not inhibit interneuron generation simply by inhibiting Shh and that Shh may not be required for generation of interneurons. An Shhindependent mechanism that is also antagonized by BMPs may promote the generation of interneurons, as noted for the generation oligodendrocytes (Nery et al., 2001). Alternatively, BMPs may act directly to inhibit the generation of interneurons by a mechanism that cannot be blocked by FGF2.

\section{References}

Alberta JA, Park SK, Mora J, Yuk D, Pawlitzky I, Iannarelli P, Vartanian T, Stiles CD, Rowitch DH (2001) Sonic hedgehog is required during an early phase of oligodendrocyte development in mammalian brain. Mol Cell Neurosci 18:434-441.

Anderson RM, Lawrence AR, Stottmann RW, Bachiller D, Klingensmith J (2002) Chordin and noggin promote organizing centers of forebrain development in the mouse. Development 129:4975-4987.

Anderson S, Mione M, Yun K, Rubenstein JL (1999) Differential origins of neocortical projection and local circuit neurons: role of Dlx genes in neocortical interneuronogenesis. Cereb Cortex 9:646-654.

Anderson SA, Eisenstat DD, Shi L, Rubenstein JL (1997a) Interneuron migration from basal forebrain to neocortex: dependence on Dlx genes. Science 278:474-476.

Anderson SA, Qiu M, Bulfone A, Eisenstat DD, Meneses J, Pedersen R, Rubenstein JL (1997b) Mutations of the homeobox genes Dlx-1 and Dlx-2 disrupt the striatal subventricular zone and differentiation of late born striatal neurons. Neuron 19:27-37.

Benson D, Watkins F, Stewared O, Banker G (1994) Characterization of GABAergic neurons in hippocampal cell cultures. J Neurocytol 23:279-295.

Bottenstein JE, Sato GH (1979) Growth of a rat neuroblastoma cell line in serum-free supplemented medium. Proc Natl Acad Sci USA 76:514-517.

Burrows RC, Wancio D, Levitt P, Lillien L (1997) Response diversity and the timing of progenitor cell maturation are regulated by developmental changes in EGFR expression in the cortex. Neuron 19:251-267.

Casarosa S, Fode C, Guillemot F (1999) Mash1 regulates neurogenesis in the ventral telencephalon. Development 126:525-534.

Cavanagh JF, Mione MC, Pappas IS, Parnavelas JG (1997) Basic fibroblast growth factor prolongs the proliferation of rat cortical progenitor cells in vitro without altering their cell cycle parameters. Cereb Cortex 7:293-302.

Chiang C, Litingtung Y, Lee E, Young KE, Corden JL, Westphal H, Beachy PA (1996) Cyclopia and defective axial patterning in mice lacking Sonic hedgehog gene function. Nature 383:407-413.

Cooper MK, Porter JA, Young KE, Beachy PA (1998) Teratogen-mediated inhibition of target tissue response to Shh signaling. Science 280:1603-1607.

Dahmane N, Ruiz-i-Altaba A (1999) Sonic hedgehog regulates the growth and patterning of the cerebellum. Development 126:3089-3100.

Dahmane N, Sanchez P, Gitton Y, Palma V, Sun T, Beyna M, Weiner H, Ruiz-i-Altaba A (2001) The Sonic Hedgehog-Gli pathway regulates dorsal brain growth and tumorigenesis. Development 128:5201-5212. 
Doetsch F, Petreanu L, Caille I, Garcia-Verdugo JM, Alvarez-Buylla A (2002) EGF converts transit-amplifying neurogenic precursors in the adult brain into multipotent stem cells. Neuron 36:1021-1034.

Eagleson KL, Ferri RT, Levitt P (1996) Complementary distribution of collagen type IV and the epidermal growth factor receptor in the rat embryonic telencephalon. Cereb Cortex 6:540-549.

Ericson J, Muhr J, Placzek M, Lints T, Jessell TM, Edlund T (1995) Sonic hedgehog induces the differentiation of ventral forebrain neurons: a common signal for ventral patterning within the neural tube. Cell 81:747-756.

Ericson J, Morton S, Kawakami A, Roelink H, Jessell TM (1996) Two critical periods of Sonic Hedgehog signaling required for the specification of motor neuron identity. Cell 87:661-673.

Furuta Y, Piston DW, Hogan BL (1997) Bone morphogenetic proteins (BMPs) as regulators of dorsal forebrain development. Development 124:2203-2212.

Gensburger C, Labourdette G, Sensenbrenner M (1987) Brain basic fibroblast growth factor stimulates the proliferation of rat neuronal precursor cells in vitro. FEBS Lett 217:1-5.

Gotz M, Bolz J (1994) Differentiation of transmitter phenotypes in rat cerebral cortex. Eur J Neurosci 6:18-32.

Grove EA, Tole S, Limon J, Yip L, Ragsdale CW (1998) The hem of the embryonic cerebral cortex is defined by the expression of multiple Wnt genes and is compromised in Gli3-deficient mice. Development 125:2315-2325.

He W, Ingraham C, Rising L, Goderie S, Temple S (2001) Multipotent stem cells from the mouse basal forebrain contribute GABAergic neurons and oligodendrocytes to the cerebral cortex during embryogenesis. J Neurosci 21:8854-8862.

Incardona JP, Gaffield W, Kapur RP, Roelink H (1998) The teratogenic Veratrum alkaloid cyclopamine inhibits sonic hedgehog signal transduction. Development 125:3553-3562.

Incardona JP, Lee JH, Robertson CP, Enga K, Kapur RP, Roelink H (2000) Receptor-mediated endocytosis of soluble and membrane-tethered Sonic hedgehog by Patched-1. Proc Natl Acad Sci USA 97:12044-12049.

Kalyani AJ, Piper D, Mujtaba T, Lucero MT, Rao MS (1998) Spinal cord neuronal precursors generate multiple neuronal phenotypes in culture. J Neurosci 18:7856-7868.

Kohtz JD, Baker DP, Corte G, Fishell G (1998) Regionalization within the mammalian telencephalon is mediated by changes in responsiveness to Sonic Hedgehog. Development 125:5079-5089.

Kohtz JD, Lee HY, Gaiano N, Segal J, Ng E, Larson T, Baker DP, Garber EA, Williams KP, Fishell G (2001) N-terminal fatty-acylation of sonic hedgehog enhances the induction of rodent ventral forebrain neurons. Development 128:2351-2363.

Letinic K, Zoncu R, Rakic P (2002) Origin of GABAergic neurons in the human neocortex. Nature 417:645-649.

Levison SW, Goldman JE (1993) Both oligodendrocytes and astrocytes develop from progenitors in the subventricular zone of postnatal rat forebrain. Neuron 10:201-212.

Li W, Cogswell CA, LoTurco JJ (1998) Neuronal differentiation of precursors in the neocortical ventricular zone is triggered by BMP. J Neurosci 18:8853-8862.

Liem Jr KF, Tremml G, Roelink H, Jessell TM (1995) Dorsal differentiation of neural plate cells induced by BMP-mediated signals from epidermal ectoderm. Cell 82:969-979.

Lillien L, Raphael H (2000) BMP and FGF regulate the development of EGFresponsive neural progenitor cells. Development 127:4993-5005.

Luskin MB, Parnavelas JG, Barfield JA (1993) Neurons, astrocytes, and oligodendrocytes of the rat cerebral cortex originate from separate progenitor cells: an ultrastructural analysis of clonally related cells. J Neurosci 13:1730-1750.

Mabie PC, Mehler MF, Kessler JA (1999) Multiple roles of bone morphogenetic protein signaling in the regulation of cortical cell number and phenotype. J Neurosci 19:7077-7088.

Marti E, Takada R, Bumcrot DA, Sasaki H, McMahon AP (1995) Distribution of Sonic hedgehog peptides in the developing chick and mouse embryo. Development 121:2537-2547.

Mehler MF, Mabie PC, Zhang D, Kessler JA (1997) Bone morphogenetic proteins in the nervous system. Trends Neurosci 20:309-317.

Mekki-Dauriac S, Agius E, Kan P, Cochard P (2002) Bone morphogenetic proteins negatively control oligodendrocyte precursor specification in the chick spinal cord. Development 129:5117-5130.
Mione MC, Danevic C, Boardman P, Harris B, Parnavelas JG (1994) Lineage analysis reveals neurotransmitter (GABA or glutamate) but not calcium-binding protein homogeneity in clonally related cortical neurons. J Neurosci 14:107-123.

Mione MC, Cavanagh JF, Harris B, Parnavelas JG (1997) Cell fate specification and symmetrical/asymmetrical divisions in the developing cerebral cortex. J Neurosci 17:2018-2029.

Nery S, Wichterle H, Fishell G (2001) Sonic hedgehog contributes to oligodendrocyte specification in the mammalian forebrain. Development 128:527-540.

Orentas DM, Hayes JE, Dyer KL, Miller RH (1999) Sonic hedgehog signaling is required during the appearance of spinal cord oligodendrocyte precursors. Development 126:2419-2429.

Parnavelas JG, Barfield JA, Franke E, Luskin MB (1991) Separate progenitor cells give rise to pyramidal and nonpyramidal neurons in the rat telencephalon. Cereb Cortex 1:463-468.

Phelps P, Alijani A, Tran T (1999) Ventrally located commissural neurons express GABAergic phenotype in developing rat spinal cord. J Comp Neurol 409:285-298.

Poncet C, Soula C, Trousse F, Kan P, Hirsinger E, Pourquie O, Duprat AM, Cochard P (1996) Induction of oligodendrocyte progenitors in the trunk neural tube by ventralizing signals: effects of notochord and floor plate grafts, and of sonic hedgehog. Mech Dev 60:13-32.

Pringle NP, Yu WP, Guthrie S, Roelink H, Lumsden A, Peterson AC, Richardson WD (1996) Determination of neuroepithelial cell fate: induction of the oligodendrocyte lineage by ventral midline cells and sonic hedgehog. Dev Biol 177:30-42.

Raballo R, Rhee J, Lyn-Cook R, Leckman JF, Schwartz ML, Vaccarino FM (2000) Basic fibroblast growth factor (Fgf2) is necessary for cell proliferation and neurogenesis in the developing cerebral cortex. J Neurosci 20:5012-5023.

Rakic P (1990) Principles of neural cell migration. Experientia 46:882-891.

Roelink H, Porter JA, Chiang C, Tanabe Y, Chang DT, Beachy PA, Jessell TM (1995) Floor plate and motor neuron induction by different concentrations of the amino-terminal cleavage product of sonic hedgehog autoproteolysis. Cell 81:445-455.

Rowitch DH, B SJ, Lee SM, Flax JD, Snyder EY, McMahon AP (1999) Sonic hedgehog regulates proliferation and inhibits differentiation of CNS precursor cells. J Neurosci 19:8954-8965.

Sidman RL, Rakic P (1973) Neuronal migration, with special reference to developing human brain: a review. Brain Res 62:1-35.

Stuhmer T, Anderson SA, Ekker M, Rubenstein JL (2002) Ectopic expression of the Dlx genes induces glutamic acid decarboxylase and Dlx expression. Development 129:245-252.

Sussel L, Marin O, Kimura S, Rubenstein JL (1999) Loss of Nkx2.1 homeobox gene function results in a ventral to dorsal molecular respecification within the basal telencephalon: evidence for a transformation of the pallidum into the striatum. Development 126:3359-3370.

Tamamaki N, Fujimori KE, Takauji R (1997) Origin and route of tangentially migrating neurons in the developing neocortical intermediate zone. J Neurosci 17:8313-8323.

Tan SS, Kalloniatis M, Sturm K, Tam PP, Reese BE, Faulkner-Jones B (1998) Separate progenitors for radial and tangential cell dispersion during development of the cerebral neocortex. Neuron 21:295-304.

Tao Y, Black IB, DiCicco-Bloom E (1996) Neurogenesis in neonatal rat brain is regulated by peripheral injection of basic fibroblast growth factor (bFGF). J Comp Neurol 376:653-663.

Tarabykin V, Stoykova A, Usman N, Gruss P (2001) Cortical upper layer neurons derive from the subventricular zone as indicated by Svetl gene expression. Development 128:1983-1993.

Tekki-Kessaris N, Woodruff R, Hall AC, Gaffield W, Kimura S, Stiles CD, Rowitch DH, Richardson WD (2001) Hedgehog-dependent oligodendrocyte lineage specification in the telencephalon. Development 128:2545-2554.

Thibert C, Teillet M, Lapointe F, Mazelin L, Le Douarin N, Mehlen P (2003) Inhibition of neuroepithelial patched-induced apoptosis by sonic hedgehog. Science 301:774-776.

Tramontin AD, Garcia-Verdugo JM, Lim DA, Alvarez-Buylla A (2003) Postnatal development of radial glia and the ventricular zone (VZ): a continuum of the neural stem cell compartment. Cereb Cortex 13:580-587.

Viti J, Gulacsi A, Lillien L (2003) Wnt regulation of progenitor maturation 
in the cortex depends on Shh or fibroblast growth factor 2. J Neurosci 23:5919-5927.

Wallace VA (1999) Purkinje-cell-derived Sonic hedgehog regulates granule neuron precursor cell proliferation in the developing mouse cerebellum. Curr Biol 9:445-448.

Watanabe T, Raff MC (1990) Rod photoreceptor development in vitro: intrinsic properties of proliferating neuroepithelial cells change as development proceeds in the rat retina. Neuron 4:461-467.

Watanabe Y, Duprez D, Monsoro-Burq AH, Vincent C, Le Douarin NM (1998) Two domains in vertebral development: antagonistic regulation by SHH and BMP4 proteins. Development 125:2631-2639.

Wechsler-Reya RJ, Scott MP (1999) Control of neuronal precursor proliferation in the cerebellum by Sonic Hedgehog. Neuron 22:103-114.
Xu Q, De La Cruz E, Anderson SA (2003) Cortical interneuron fate determination: diverse sources for distinct subtypes? Cereb Cortex 13:670-676.

Yung SY, Gokhan S, Jurcsak J, Molero AE, Abrajano JJ, Mehler MF (2002) Differential modulation of BMP signaling promotes the elaboration of cerebral cortical GABAergic neurons or oligodendrocytes from a common sonic hedgehog-responsive ventral forebrain progenitor species. Proc Natl Acad Sci USA 99:16273-16278.

Zeng X, Goetz JA, Suber LM, Scott Jr WJ, Schreiner CM, Robbins DJ (2001) A freely diffusible form of Sonic hedgehog mediates long-range signalling. Nature 411:716-720.

Zhu G, Mehler MF, Zhao J, Yu Yung S, Kessler JA (1999) Sonic hedgehog and BMP2 exert opposing actions on proliferation and differentiation of embryonic neural progenitor cells. Dev Biol 215:118-129. 